\title{
Characterization of Bois Noir Isolates by Restriction Fragment Length Polymorphism of a Stolbur-Specific Putative Membrane Protein Gene
}

\author{
D. Pacifico, A. Alma, B. Bagnoli, X. Foissac, G. Pasquini, M. Tessitori, and C. Marzachì
}

First and seventh authors: Istituto di Virologia Vegetale, CNR, Strada delle Cacce, 73, I-10135 Torino, Italy; second author: Di.Va.P.R.A.Entomologia e Zoologia Applicate all'Ambiente "C. Vidano", Università degli Studi di Torino, via L. da Vinci, 44, 10095, Grugliasco (TO), Italy; third author: Istituto Sperimentale per la Zoologia Agraria, CRA, via Lanciola, 12/A, 50125 Firenze, Italy; fourth author: UMR-1090 Génomique Diversité Pouvoir Pathogène, INRA, Université de Bordeaux 2, 71 avenue Edouard Bourlaux BP81, F-33883 Villenave d'Ornon, France; fifth author: Istituto Sperimentale per la Patologia Vegetale, CRA, via C.G. Bertero, 22, I-00156 Roma, Italy; and sixth author: Dipartimento di Scienze e Tecnologie Fitosanitarie, Università degli Studi di Catania, Via S. Sofia, 100, I-95123 Catania, Italy.

Accepted for publication 11 January 2009.

\begin{abstract}
Pacifico, D., Alma, A., Bagnoli, B., Foissac, X., Pasquini, G., Tessitori, M., and Marzachì, C. 2009. Characterization of Bois noir isolates by restriction fragment length polymorphism of a Stolbur-specific putative membrane protein gene. Phytopathology 99:711-715.

Bois noir phytoplasma (BNp), widespread in wine-producing areas of Europe and endemic in France and Italy, is classified in the 16SrXII-A subgroup, whose members are referred to as Stolbur phytoplasmas. The 16S rDNA gene of Stolbur phytoplasma shows low variability, and few non-ribosomal genes are available as markers to assess variation among isolates. We used the Stolbur-specific stol-1H10 gene, encoding a putative membrane-exposed protein, to investigate genetic diversity of French and

from infected grapevines, weeds, and Hyalesthes obsoletus produced fragments of three sizes, and restriction fragment length polymorphism analysis divided these amplicons further into 12 profiles (V1 to V12). French $\mathrm{BNp}$ isolates were more variable than Italian ones, and different profiles were present in infected grapevines from France and Italy. Isolate V3, most abundant among Italian affected grapes but present among French ones, was found in one Urtica dioica sample and in all H. obsoletus collected on this species. Four Italian-specific profiles were represented among infected Convolvulus arvensis, the most frequent of which (V12) was also detected in H. obsoletus collected on this species. Most of the variability in the stol-1H1O sequence was associated with type II on the tuf gene.
\end{abstract} Italian BNp isolates from plants and insects. Amplification of stol-1H1O
Phytoplasmas in the 16SrXII-A taxonomic subgroup (suggested name 'Candidatus Phytoplasma solani') are associated with Stolbur disease in a wide range of wild and cultivated plants in continental and Mediterranean Europe, causing severe losses of annual crops (16). Important perennials also suffer from Stolbur phytoplasma diseases such as grapevine yellows (GY) Vergilbungskrankheit (VK) in Germany (13), also known as Bois noir $(\mathrm{BN})$ in most European wine-producing Regions (2). BN has been present in Italian and French vineyards for a long time but there are recent reports of increased spread of the disease in Italy $(1,9,22,23)$.

In the Euro-Mediterranean Region, phloem-feeding Hemiptera of the Cixiidae family are the vectors of Stolbur phytoplasmas (29). The planthopper Hyalesthes obsoletus is responsible for BN transmission to grapevine (26). Adult $H$. obsoletus can feed on various herbaceous plants but only a few species are selected to complete its life cycle. In Germany, Convolvulus arvensis, Calystegia sepium, and Urtica dioica are reported as preferred hosts for reproduction (8) whereas, in Italy, H. obsoletus nymphs have so far been found only on $U$. dioica (12).

Restriction fragment length polymorphism (RFLP) and sequence analyses of the 16SrDNA show low variability among

Corresponding author: C. Marzachì; E-mail address: c.marzachi@ivv.cnr.it

doi:10.1094/PHYTO-99-6-0711

(C) 2009 The American Phytopathological Society
Stolbur isolates from different regions and host plants (16). However, biological and genomic diversity exist. Periwinkle plants, experimentally infected with different isolates, can show different symptoms (20), and variation in genome size has also been reported (15). Based on polymerase chain reaction (PCR)RFLP analysis of the tuf gene, three tuf types (I-III) have recently been characterized in Germany in infected grapevines as well as in the vector $H$. obsoletus and in weeds. Each type was specifically associated with different herbaceous species and vector populations, suggesting the presence of three natural cycles of VK phytoplasma in German vineyards (8).

Analysis of the tuf gene has been successfully adopted to investigate the epidemiology of BN phytoplasma (BNp) in Italian vineyards. Preliminary results showed the presence of two BNp isolates corresponding to tuf types I and II $(1,9,22)$. Tuf I was also found in vectors collected on $U$. dioica in vineyards where this is the predominant weed $(3,12)$.

Recently, a new approach based on molecular subtraction hybridization was used to obtain enriched genomic libraries of the French Stolbur isolate PO (4). The stol-1H1O gene, encoding a putative membrane protein absent in ' $\mathrm{Ca}$. P. asteris' but sharing low similarity with a variable surface lipoprotein of Mycoplasma agalactiae, was used as genetic marker to assess the variability of different periwinkle-maintained Stolbur isolates, using PCRRFLP (20). In the present work, we used this gene as a marker to investigate the genetic diversity of French and Italian $\mathrm{BNp}$ isolates from plants and insects. 


\section{MATERIALS AND METHODS}

Plant and insect samples. In 2004, 2005, and 2006, 28, 43, and 60 leaf samples, respectively, were collected from BNinfected grapevines of several cultivars in seven Italian traditional grapevine-growing regions. We also included in our survey 111 BN isolates from grapevines collected in 2004 from vineyards in 10 different areas in France (Table 1). Herbaceous weeds were also collected in BN-infected vineyards in northwestern Italy (Piemonte and Valle d'Aosta) during summer 2005 and 2006. In each vineyard, either $C$. arvensis or $U$. dioica were the predominant weeds. Eleven $C$. arvensis samples were collected from plants showing stunting and strong leaf reduction in six Piemonte vineyards in 2005 and 2006. Yellows and stunting were also observed on four $U$. dioica plants collected in two BN-infected vineyards in Piemonte in 2005 and one sample in Valle d'Aosta in 2006.

In all, 30, 55, and 17 adult $H$. obsoletus individuals were collected in a vineyard in Lazio and in several vineyards in Valle d'Aosta and Piemonte, respectively, during June to July 2006. All insects were collected from nettle, except three adults taken on bindweed in one vineyard in Piemonte.

A Sardinian strain of Stolbur from tomato (T2_92) maintained in periwinkle in the collection of the Istituto di Virologia Vegetale, CNR (19) was used as reference isolate and positive control in PCR experiments.

Total DNA extraction and phytoplasma identification. Total DNA was extracted from $1.5 \mathrm{~g}$ of fresh grapevine and $U$. dioica midribs and from leaves, stems, and petioles of symptomatic $C$. arvensis plants following a modified cetyltrimethylammonium bromide protocol (17). The DNA was finally suspended in $100 \mu \mathrm{l}$ of sterile distilled water (SDW).

Total DNA was extracted from single $H$. obsoletus individuals, fresh or stored under $70 \%$ ethanol at $4{ }^{\circ} \mathrm{C}$ using the method of Marzachì et al. (18). The purified DNA was suspended in $100 \mu \mathrm{l}$ of SDW.

To confirm the presence of BNp in single infection, $2 \mu \mathrm{l}$ of each DNA extract was used in PCR assays with the universal ribosomal primers P1/P7 (25). Of the 1:40 diluted products of the first PCR, $2 \mu \mathrm{l}$ was used as template for nested PCRs with the groupspecific ribosomal primers R16(I)F1/R1 and R16(V)F1/R1 (11). PCR mixtures and cycling conditions were as described in the original articles. Taq DNA polymerase (1 U) (Polymed, Firenze, Italy) was used in each assay. PCR products were analyzed by electrophoresis through $1 \%$ agarose gel in $1 \times$ Tris-borate-EDTA (TBE) buffer along with a 1-kb-plus DNA size marker (Gibco BRL, Paislay, UK). Gels were stained with ethidium bromide and

TABLE 1. Geographic origin of Bois noir-affected grapevines

\begin{tabular}{lc}
\hline Country of origin, region & Number of isolates \\
\hline France & 17 \\
Alsace & 27 \\
Aquitaine & 16 \\
Bourgogne & 3 \\
Centre & 10 \\
Languedoc-Roussillon & 7 \\
Midi-Pyrénées & 5 \\
Pays de la Loire & 10 \\
Poitou-Charente & 7 \\
Provence-Alpes-Côte d'Azur & 9 \\
Rhône-Alpes & \\
Italy & 13 \\
Lazio & 1 \\
Liguria & 75 \\
Piemonte & 1 \\
Sardegna & 8 \\
Sicilia & 13 \\
Toscana & 20 \\
Valle d'Aosta & \\
\hline
\end{tabular}

visualized on a UV transilluminator. To confirm each isolate as a member of the 16SrXII-A subgroup, nested R16(I)F1/R1 PCR amplicons were digested with $2.5 \mathrm{U}$ of MseI (Invitrogen, Carlsbad, CA), according to the manufacturer's instructions. The restriction fragments, together with the 1-kb-plus DNA size marker (Gibco BRL), were separated by $8 \%$ polyacrylamide gel electrophoresis in $1 \times$ TBE buffer and stained and visualized as before.

Characterization of $\mathbf{B N}$ isolates. Following identification, $\mathrm{BN}$ isolates were characterized by PCR-RFLP analysis of two nonribosomal genomic regions: tuf (8) and stol-1H10. Primers fTufAY/rTufAY (24) were used to amplify a 940-bp fragment of the tuf gene from Italian $\mathrm{BN}$ isolates. Of the 1:40 diluted products of the first PCR, $2 \mu \mathrm{l}$ was used as template for nested PCRs driven by primers fTufu/rTufu (24), using $1 \mathrm{U}$ of Taq DNA polymerase (Polymed). The fTufu/rTufu amplicons (850 bp) were digested with $2.5 \mathrm{U}$ of endonuclease HpaII (Invitrogen) according to manufacturer's instructions.

Stolbur-specific primers H10F1 (5'AGGTTGTAAAATCTTTTATGT3') and H10R1 (5'GCGGATGGCTTTTCATTATTTGAC $3^{\prime}$ ) overlapping the start and stop codons, respectively, of the stol-1H1O gene were used to amplify the complete stol-1H1O gene. PCRs were performed in a final mixture of $40 \mu$ containing 10 to $100 \mathrm{ng}$ of total DNA, $0.5 \mu \mathrm{M}$ each primer, $200 \mu \mathrm{M}$ dNTPs, $2 \mathrm{mM} \mathrm{MgCl}_{2}$, and $1 \mathrm{U}$ of Taq polymerase (Polymed) in the buffer supplied. Cycling conditions were as follows: denaturation for $5 \mathrm{~min}$ at $94^{\circ} \mathrm{C}$; followed by 35 cycles of $30 \mathrm{~s}$ at $94^{\circ} \mathrm{C}, 30 \mathrm{~s}$ at $52^{\circ} \mathrm{C}$, and $1 \mathrm{~min} 45 \mathrm{~s}$ at $72^{\circ} \mathrm{C}$; and a post-dwell period of $10 \mathrm{~min}$ at $72^{\circ} \mathrm{C}$. The first PCR was followed by a nested PCR with internal primers H10F2 (5'TGTCACAGGGAAACAGACAG3') and H10R2 (5'CACAAACATGATGATTATCAACGA3'). These reactions were carried out in the same conditions as the first PCR using $0.5 \mu \mathrm{l}$ of the first PCR product as template. The products of the nested PCR ( 2 to $4 \mu \mathrm{l}$ ) were singly digested with $2.5 \mathrm{U}$ of $R s a \mathrm{I}$ or $A l u \mathrm{I}$ restriction enzymes (Invitrogen) according to the manufacturer's instructions. PCR products were analyzed by electrophoresis through $1 \%$ agarose gel, then stained and visualized as above. Restriction fragments were always separated by electrophoresis on $8 \%$ polyacrylamide gels in $1 \times$ TBE buffer and visualized as detailed above, and 1-kb-plus DNA (Gibco BRL) was used as size marker.

\section{RESULTS}

BN detection. Stolbur-specific RFLP profiles were identified on the $16 \mathrm{~S}$ rDNA amplicons of all the symptomatic Italian grapevine samples, 10 of 11 C. arvensis samples, 1 of 5 U. dioica, and 65 of $102 \mathrm{H}$. obsoletus individuals (not shown). No Flavescence dorée-specific amplicons were detected following amplification of DNA from the infected grapevines with R16(V)F1/R1 primers (11). No amplification was obtained from healthy grapevines or symptomless weeds.

Diversity of the tuf gene in Italian BN isolates from grapevine, weeds, and $\boldsymbol{H}$. obsoletus. Fragments of the expected size (840 bp) were amplified in nested PCR assays from all Stolburaffected Italian grapevines, $9 \mathrm{C}$. arvensis, $1 \mathrm{U}$. dioica, and $51 \mathrm{H}$. obsoletus individuals. No amplification was obtained from healthy grapevines or symptomless $C$. arvensis and $U$. dioica. RFLP analysis showed the presence of tuf type I and II (8) in BN-infected grapevines from Piemonte (52 and 48\%, respectively) and Valle d'Aosta (Table 2). Only tufII was detected in BN-infected grapevines from Sicilia, Sardegna, and Toscana, whereas only tufI was found in $\mathrm{BN}$-infected grapevines from Lazio and Liguria.

TufI was found in $U$. dioica in Valle d'Aosta whereas only tufII was detected in $C$. arvensis in Piemonte. H. obsoletus from nettle in Piemonte and Valle d'Aosta harbored only tufl, whereas $H$. obsoletus collected on $C$. arvensis in Piemonte contained tufII. Only tufI was present in insects from Lazio (Table 2). 
Diversity of the stol-1H10 gene in BN isolates from grapevine. Nested PCR with primers H10F2/H10R2 amplified specific bands from 48 of 111 French BN isolates and 102 of 131 Italian $\mathrm{BN}$ isolates. No amplification was obtained from healthy grapevines. Amplicons of 1,570 bp were obtained from 3 French grapevine isolates whereas the remaining 45 produced a specific band of 1,820 bp. In all, 1 Italian isolate generated a PCR product of $1,570 \mathrm{bp}$ and 80 isolates produced bands of $1,820 \mathrm{bp}$, whereas a larger amplicon $(2,070 \mathrm{bp})$ was obtained from the remaining 21 samples collected in Piemonte and Toscana (northwestern and central Italy) (Fig. 1).

BN-specific amplicons restricted with RsaI showed 11 distinct patterns (V types), ranging from V1 to V11 (Fig. 2A and B). Four different $\mathrm{V}$ types (V5, V6, V7, and V8) were obtained by di-

TABLE 2. Distribution of tuf type I and II in Bois noir-infected grapevines and Hyalesthes obsoletus from different Italian Regions

\begin{tabular}{lrrrcc}
\hline & \multicolumn{2}{c}{ Grapevine } & & \multicolumn{2}{c}{ H. obsoletus } \\
\cline { 2 - 3 } \cline { 5 - 6 } Origin & tuf & tufII & & tufI & tufII \\
\hline Piemonte & 39 & 36 & & 9 & 3 \\
Lazio & 13 & 0 & & 8 & 0 \\
Liguria & 1 & 0 & & $\ldots$ & $\ldots$ \\
Sardegna & 0 & 1 & & $\ldots$ & $\ldots$ \\
Sicilia & 0 & 8 & & $\ldots$ & $\ldots$ \\
Toscana & 0 & 14 & & $\ldots$ & $\ldots$ \\
Valle d'Aosta & 17 & 2 & & 31 & 0 \\
Total & 70 & 61 & & 48 & 3 \\
\hline
\end{tabular}

$\begin{array}{llllllllllllllllllllllll}\text { g1 } & \text { g2 } & \text { g3 } & \text { g4 } & \text { g5 } & \text { g6 } & \text { g7 } & \text { g8 } & \text { g9 } & \text { g10 } & \text { g11 } & \text { g1 } & \text { h } & \text { M }\end{array}$

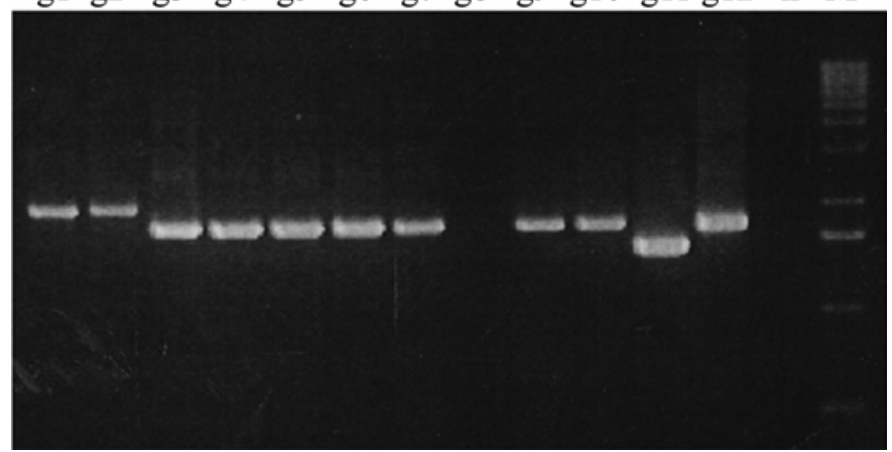

Fig. 1. Agarose gel showing the size polymorphism of polymerase chain reaction products obtained with primers $\mathrm{H} 10 \mathrm{~F} 1 / \mathrm{R} 1$ followed by primers H10F2/R2 from grapevine (g) Bois noir isolates. M, 1-kb-plus DNA size marker (Gibco BRL, Paislay, UK); g1-g12, grapevine Bois noir isolates from Piemonte; h, healthy grapevine DNA control. gestion of the 1,570-bp band and seven types (V1, V2, V3, V4, V9, V10, and V11) from the 1,820-bp band. The RsaI profile of the 2,070-bp band produced a pattern similar to type V11 due to poor resolution of larger DNA fragments but restriction with AluI resulted in a new V12 profile (Fig. 2C). V3 and V5 profiles were unique to tuf type I isolates, V1 was present in both tuf types I and II isolates, whereas the remaining V profiles isolated from Italian grapevines were associated with tuf type II isolates.

Seven of the RFLP V types (V1, V2, V3, V4, V6, V7, and V8) were detected in French grapevine BN isolates. V1 was the most abundant $(39.5 \%)$ and V4 was detected in samples from almost all French regions. In all, 10 and $12 \%$ of the profiles were V2 and V3 types. V6, V7, and V8 patterns were detected in a few samples from three French regions (Table 3 ).

Nine V types (V1, V2, V3, V4, V5, V9, V10, V11, and V12) were obtained from Italian grapevine isolates. V5 was only detected in one isolate from Piemonte. V1, V2, and V4 were detected in $\approx 5 \%$ of the samples analyzed. V3 was the most abundant in northwestern regions and Lazio, representing $\approx 64 \%$ of all Italian isolates, whereas it was not detected in isolates from Toscana, Sicilia, or Sardegna. Types V9 to V12 were only detected in Italian isolates; V9 type was present in northwestern regions and in Sicilia, V10 was present only in few grapevines from Piemonte, whereas V11 was present in Sardegna. V12 type was detected in $\approx 29 \%$ of the isolates from Piemonte and in four of five isolates from Toscana (Table 3).

Diversity of the stol-1H10 gene in $\mathrm{BN}$ isolates from weeds and vectors. Specific bands were obtained in nested PCR with primers $\mathrm{H} 10 \mathrm{~F} 2 / \mathrm{H} 10 \mathrm{R} 2$ from the $U$. dioica sample, 8 C. arvensis samples, and $45 \mathrm{H}$. obsoletus individuals. Middle-sized PCR amplicons $(1,820 \mathrm{bp})$ were obtained from the infected nettle, $4 C$. arvensis, and $42 \mathrm{H}$. obsoletus captured on $U$. dioica. Large amplicons (2,070 bp) were only obtained from four $C$. arvensis isolates from Piemonte and three $H$. obsoletus collected on $C$. arvensis from the same area (not shown). $\mathrm{BN}$-infected $U$. dioica sampled in Valle d'Aosta and $98 \%$ of insects collected on $U$. dioica were characterized as V3 (Table 4) and only one individual captured on nettle was characterized as V1. Four C. arvensis BN isolates were characterized as V9, 10, or 11 and four were V12 (Table 4). BN isolates from vectors collected on $C$. arvensis were all of type V12 (Table 4).

\section{DISCUSSION}

RFLP of $16 \mathrm{~S}$ ribosomal RNA genes of grapevine BN isolates collected in Italy confirmed our isolates as members of the 16SrXII-A taxonomic subgroup but, as expected, did not allow differentiation among isolates of different years or differ-
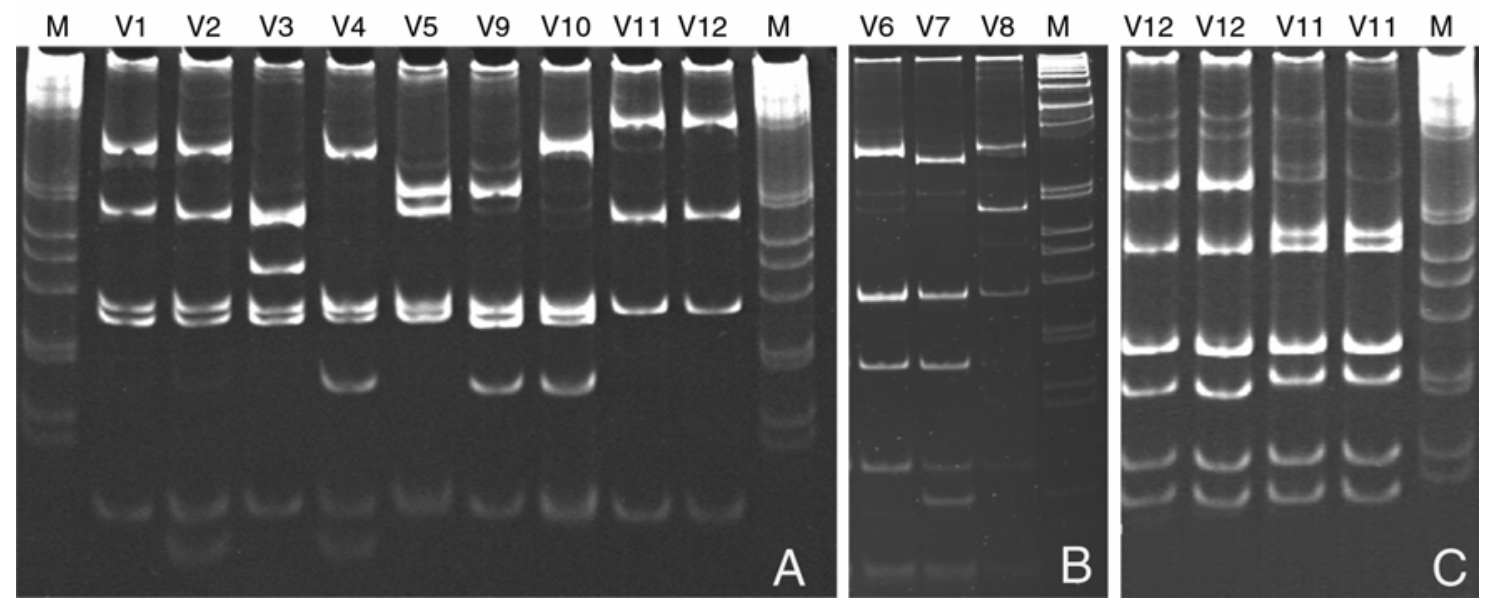

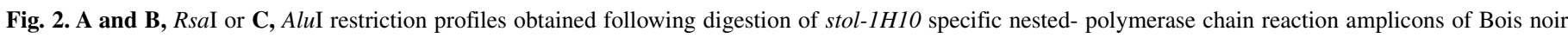
isolates (V1-V12). 
ent geographic origins, due to low variability on the 16SrDNA region.

Diversity in the tuf gene has been successfully used in Germany for differentiation of phytoplasmas associated with grapevine VK (8). In Piemonte and Valle d'Aosta, we detected both tufI and tufII types, present in affected grapevines and $H$. obsoletus individuals, but associated with nettle or bindweed, respectively. The low number of sampling sites as well as plant or vector samples collected are not representative of the BN situation in central and southern Italy, although our results confirm the prevalence of tuf type I in BN-affected grapevines and vectors from Lazio (22). Tuf type III, detected in Germany in BN-affected grapevines, in $H$. obsoletus, and in its herbaceous host Calystegia sepium (8), was not found in our survey of Italian BN isolates.

Our results show that the stol-1H1O gene is variable enough to study genetic diversity among $\mathrm{BN}$ isolates. We have shown that amplification of the stol-1H10 gene from field-collected $\mathrm{BN}$ infected grapevines, weeds, and $H$. obsoletus individuals may result in amplicons of three sizes. The largest amplicon was detected only in Italian $\mathrm{BN}$ isolates from grapevine and $C$. arvensis and $H$. obsoletus captured on this species, while the medium-size amplicon was the most abundant among isolates collected in Italy and France. The lack of amplification of the stol-1H10 gene from $\approx 20 \%$ of Italian $\mathrm{BN}$-affected plant samples may be due to lower efficiency of the stol-1H10-based primers compared with the ribosomal-based ones, although we cannot exclude sequence mismatches in the template DNA. The negative PCR results obtained from some French grapevines is probably also due to the quality of template DNA tested almost 2 years after extraction and first identification of $\mathrm{BN}$ infection.

RFLP analysis of stol-1H1O amplicons from BN-infected grapevines, weeds, and vectors resulted in 12 profiles, 5 of which
(V3, V5, V9, V10, and V12) were not previously described, while the remaining ones were indistinguishable from those of periwinkle-maintained Stolbur isolates from horticultural and other hosts (20). The same analysis showed that different stol-1H10 profiles were prevalent in France and Italy. Actually, five RFLP patterns were found only in Italy while three were detected among French grapevine BN isolates but were absent in the Italian ones, regardless of the host. Two profiles accounted for $>70 \%$ of the BN diversity: V3 and V12 in Italy and V1 and V4 in France. Although the number of characterized $\mathrm{BN}$ isolates from France was lower than the Italian ones, we have shown that the most representative isolates in Italy and France are different. Our results, therefore, do not support a major role of import of infected material in spreading the disease between the two countries.

RFLP analysis of stol-1H10 amplicons indicated that four profiles were represented among Stolbur-infected $C$. arvensis, the most frequent of which (V12) was also detected in the $H$. obsoletus individuals collected on this species. We also found that severe growth reduction was clearly associated with $\mathrm{BN}$ infection in $C$. arvensis. RFLP analysis of stol-1H10 amplicons also showed that the $\mathrm{V} 3$ profile, the most abundant among Italian $\mathrm{BN}$ affected vines and also present among French isolates, was detected in the majority of $H$. obsoletus collected on $U$. dioica and in the only Stolbur-positive sample of this plant. $U$. dioica hosts high populations of $H$. obsoletus in Northern Italy $(3,12)$ but the percentage of Stolbur-infected plants that we found in our survey was very low. The only Stolbur-infected $U$. dioica plant showed no obvious symptoms. Asymptomatic phytoplasma infections have been reported for several species (10). In these cases, identification of infected plants is difficult; moreover, phytoplasma detection in $U$. dioica is erratic even when DNA enrich-

TABLE 3. Distribution of stol-1H10 restriction fragment length polymorphism (RFLP) profiles (V) in grapevines from France and Italy

\begin{tabular}{|c|c|c|c|c|c|c|c|c|c|c|c|c|}
\hline \multirow[b]{2}{*}{ Country, region ${ }^{\mathrm{a}}$} & \multicolumn{12}{|c|}{ RFLP type } \\
\hline & V1 & $\mathrm{V} 2$ & V3 & V4 & V5 & V6 & V7 & V8 & V9 & V10 & V11 & V12 \\
\hline \multicolumn{13}{|l|}{ France } \\
\hline Alsace & 2 & 4 & 2 & 2 & $\ldots$ & $\ldots$ & $\ldots$ & $\ldots$ & $\ldots$ & $\ldots$ & $\ldots$ & $\ldots$ \\
\hline Aquitaine & 2 & $\ldots$ & 1 & 2 & $\ldots$ & $\ldots$ & $\ldots$ & $\ldots$ & $\ldots$ & $\ldots$ & $\ldots$ & $\ldots$ \\
\hline Bourgogne & 6 & $\ldots$ & $\ldots$ & $\ldots$ & $\ldots$ & $\ldots$ & $\ldots$ & 1 & $\ldots$ & $\ldots$ & $\ldots$ & $\ldots$ \\
\hline Centre & $\ldots$ & $\ldots$ & 1 & 2 & $\ldots$ & $\ldots$ & $\ldots$ & $\ldots$ & $\ldots$ & $\ldots$ & $\ldots$ & $\ldots$ \\
\hline Languedoc-Roussilion & $\ldots$ & $\ldots$ & $\ldots$ & 1 & $\ldots$ & $\ldots$ & 1 & $\ldots$ & $\ldots$ & $\ldots$ & $\ldots$ & $\ldots$ \\
\hline Midi-Pyrénées & $\ldots$ & $\ldots$ & 2 & 1 & $\ldots$ & 1 & $\ldots$ & $\ldots$ & $\ldots$ & $\ldots$ & $\ldots$ & $\ldots$ \\
\hline Pays de la Loire & 3 & $\ldots$ & $\ldots$ & $\ldots$ & $\ldots$ & $\ldots$ & $\ldots$ & $\ldots$ & $\ldots$ & $\ldots$ & $\ldots$ & $\ldots$ \\
\hline Poitou-Charente & 3 & 1 & $\ldots$ & 3 & $\ldots$ & $\ldots$ & $\ldots$ & $\ldots$ & $\ldots$ & $\ldots$ & $\ldots$ & $\ldots$ \\
\hline Provence-Alpes-Côte d'Azur & $\ldots$ & $\ldots$ & $\ldots$ & 2 & $\ldots$ & $\ldots$ & $\ldots$ & $\ldots$ & $\ldots$ & $\ldots$ & $\ldots$ & $\ldots$ \\
\hline Rhône-Alpes & 3 & $\ldots$ & $\ldots$ & 2 & $\ldots$ & $\ldots$ & $\ldots$ & $\ldots$ & $\ldots$ & $\ldots$ & $\ldots$ & $\ldots$ \\
\hline Total & 19 & 5 & 6 & 15 & $\ldots$ & 1 & 1 & 1 & $\ldots$ & $\ldots$ & $\ldots$ & $\ldots$ \\
\hline \multicolumn{13}{|l|}{ Italy } \\
\hline Lazio & $\ldots$ & $\cdots$ & 11 & $\cdots$ & $\cdots$ & $\ldots$ & $\ldots$ & $\ldots$ & $\ldots$ & $\cdots$ & $\ldots$ & $\ldots$ \\
\hline Liguria & $\ldots$ & $\ldots$ & 1 & $\ldots$ & $\ldots$ & $\ldots$ & $\ldots$ & $\ldots$ & $\ldots$ & $\ldots$ & $\ldots$ & $\ldots$ \\
\hline Piemonte & $\ldots$ & $\ldots$ & 38 & $\ldots$ & 1 & $\ldots$ & $\ldots$ & $\ldots$ & 1 & 2 & $\ldots$ & 17 \\
\hline Sardegna & $\ldots$ & $\ldots$ & $\ldots$ & $\ldots$ & $\ldots$ & $\ldots$ & $\ldots$ & $\ldots$ & $\ldots$ & $\ldots$ & 1 & $\ldots$ \\
\hline Sicilia & $\ldots$ & 1 & $\ldots$ & 2 & $\ldots$ & $\ldots$ & $\ldots$ & $\ldots$ & 4 & $\ldots$ & $\ldots$ & $\ldots$ \\
\hline Toscana & 1 & $\ldots$ & $\ldots$ & $\ldots$ & $\ldots$ & $\ldots$ & $\ldots$ & $\ldots$ & $\ldots$ & $\ldots$ & $\ldots$ & 4 \\
\hline Valle d'Aosta & 1 & $\ldots$ & 15 & $\ldots$ & $\ldots$ & $\ldots$ & $\ldots$ & $\ldots$ & 2 & $\ldots$ & $\ldots$ & $\ldots$ \\
\hline Total & 2 & 1 & 65 & 2 & 1 & $\ldots$ & $\ldots$ & $\ldots$ & 7 & 2 & 1 & 21 \\
\hline
\end{tabular}

a Origin of isolate.

TABLE 4. Distribution of stol-1H10 restriction fragment length polymorphism (RFLP) profiles (V) in Convolvulus arvensis, Urtica dioica, and Hyalesthes obsoletus individuals sampled in different Italian regions

\begin{tabular}{|c|c|c|c|c|c|c|c|c|c|c|c|c|c|}
\hline \multirow[b]{2}{*}{ Species } & \multirow[b]{2}{*}{ Origin } & \multicolumn{12}{|c|}{ RFLP type } \\
\hline & & V1 & $\mathrm{V} 2$ & V3 & V4 & V5 & V6 & V7 & V8 & V9 & V10 & V11 & V12 \\
\hline C. arvensis & Piemonte & $\ldots$ & $\ldots$ & $\ldots$ & $\ldots$ & $\ldots$ & $\ldots$ & $\ldots$ & $\ldots$ & 1 & 2 & 1 & 4 \\
\hline$U$. dioica & Valle d'Aosta & $\ldots$ & $\ldots$ & 1 & $\ldots$ & $\ldots$ & $\ldots$ & $\ldots$ & $\ldots$ & $\ldots$ & $\ldots$ & $\ldots$ & $\ldots$ \\
\hline H. obsoletus & Lazio & $\ldots$ & $\ldots$ & 8 & $\ldots$ & $\ldots$ & $\ldots$ & $\ldots$ & $\ldots$ & $\ldots$ & $\ldots$ & $\ldots$ & $\ldots$ \\
\hline H. obsoletus & Piemonte & $\ldots$ & $\ldots$ & 6 & $\ldots$ & $\ldots$ & $\ldots$ & $\ldots$ & $\ldots$ & $\ldots$ & $\ldots$ & $\ldots$ & 3 \\
\hline H. obsoletus & Valle d'Aosta & 1 & $\ldots$ & 27 & $\ldots$ & $\ldots$ & $\ldots$ & $\ldots$ & $\ldots$ & $\ldots$ & $\ldots$ & $\ldots$ & $\ldots$ \\
\hline
\end{tabular}


ment protocols are used (8). All these reasons may explain the low percentage of infected nettles collected in our surveys. The small number of infected plants collected in Sicilia, Sardegna, and Toscana may explain the absence of $\mathrm{V} 3$ profiles among grapevine $\mathrm{BN}$ isolates from these regions.

We confirm the presence of the $U$. dioica-H. obsoletus-Vitis vinifera epidemiological cycle in northwestern Italy (12) but present strong evidence of the importance of at least a second cycle, involving $C$. arvensis $-H$. obsoletus $-V$. vinifera. Stolbur phytoplasma has been detected in individuals of several Cixiidae $(21,27)$ and the role of vectors has been confirmed for some of them $(7,29)$. Moreover, other leafhoppers have been reported as natural hosts of Stolbur phytoplasma in Sardegna (5).

Gene stol-1H10 represents a genetic marker more variable than other non-ribosomal loci, because at least three stol-1H10 RFLP profiles are associated with a single profile on the tuf gene. Most of the variability on the stol-1H1O sequence is associated with the tufII profile, which has been reported in South Tyrol (Northern Italy) only since 2004 (1). This BN isolate, linked to the $C$. arvensis $-H$. obsoletus $-V$. vinifera cycle, was the most abundant and endemic isolate in Germany (28) until the recent outbreaks of the tufl-type BN isolate. These outbreaks have been linked to the concurrent spread of nettle, harboring this tufl-type isolate, and vector population adapted to this weed (14), although only subtle differences were found between $H$. obsoletus host plant populations (6).

Although more vector individuals as well as weeds need to be tested, only two stol-1H10 RFLP profiles were present in both a plant host (grapevine and alternative host plant) and $H$. obsoletus tested in Italy. The epidemiological cycles of the remaining isolates are yet to be defined.

\section{ACKNOWLEDGMENTS}

This work was financed by Ministero delle Politiche Agricole e Forestali (finalized Project: "Grapevine yellows"), Regione Piemonte, and the Regional Council of Aquitaine. We thank R. G. Milne for critical reading of the manuscript and helpful suggestion; and O. Locci from ERSAT-Italy, R. Mazzilli, R. Bonfanti from Servizio Fitosanitario Regionale/Valle d'Aosta, and R. Cavicchini from Servizio Fitosanitario Regionale/Liguria for kindly supplying phytoplasma-infected grapevines.

\section{LITERATURE CITED}

1. Baric, S., and Dalla-Via, J. 2007. Temporal sights of Bois noir phytoplasma types infecting grapevine in South Tyrol (Northern Italy). Vitis 46:101-102

2. Boudon-Padieu, E. 2003. The situation of grapevine yellows and current research directions: distribution, diversity, vectors, diffusion and control. Pages 47-50 in: Extended Abstr. 14th Meet. ICVG. Locorotondo (Bari), Italy.

3. Bressan, A., Turata, R., Maixner, M., Spiazzi, S., Boudon-Padieu, E., and Girolami, V. 2007. Vector activity of Hyalesthes obsoletus living on nettles and transmitting a Stolbur phytoplasma to grapevines: a case study. Ann. Appl. Biol. 150:331-339.

4. Cimerman, A., Arnaud, G., and Foissac, X. 2006. Stolbur phytoplasma genome survey achieved using a suppression subtractive hybridization approach with high specificity. Appl. Environ. Microbiol. 72:3274-3283.

5. Garau, R., Sechi, A., Tolu, G., Prota, V. A, Lentini, A., and Prota, U. 2004. Goniagnathus guttulinervis (Kirschbaum), new natural host of the Stolbur subgroup 16SrXII-A phytoplasma in Sardinia. J. Plant Pathol. 86:179.

6. Johannesen, J., Lux, B., Michel, K., Seitz, A., and Maixner, M. 2008. Invasion biology and host specificity of the grapevine yellows disease vector Hyalesthes obsoletus in Europe. Entomol. Exp. Appl. 126:217-227.

7. Jovic, J., Cvrkovic, T., Mitrovic, M., Krnjajic, S., Redinbaugh, M. G, Pratt, R. C., Gingery, R. E, Hogenhout, S. A., and Toševski, I. 2007. Roles of Stolbur phytoplasma and Reptalus panzeri (Cixiinae, Auchenorrhyncha) in the epidemiology of maize redness in Serbia. Eur. J. Plant Pathol. 118:85-89.

8. Langer, M., and Maixner, M. 2004. Molecular characterization of grapevine yellows associated phytoplasmas of the Stolbur-group based on RFLP-analysis of non-ribosomal DNA. Vitis 43:191-200.

9. La Rosa, R., Tessitori, M., Pacifico, D., Marzachì, C., Cirvilleri, G., Rapisarda, C., and D'urso, V. 2006. Detection and characterization of grapevine phytoplasmas in Sicilia (Italy). Pages 216-217 in: Extended Abstr. 15th Meet. ICVG. Stellenbosch, South Africa.

10. Lee, I. M., Davis, R. E., and Gundersen-Rindal, D. E. 2000. Phytoplasma: phytopathogenic mollicutes. Annu. Rev. Microbiol. 54:221-255.

11. Lee, I. M., Gundersen, D. E., Hammond, R. W, and Davis, R. E. 1994. Use of mycoplasmalike organism (MLO) group-specific oligonucleotide primers for nested-PCR assays to detect mixed-MLO infections in a single host plant. Phytopathology 84:559-566.

12. Lessio, F., Tedeschi, R., and Alma, A. 2007. Population dynamics, host plants and infection rate with Stolbur phytoplasma of Hyalesthes obsoletus Signoret in north-western Italy. J. Plant Pathol. 89:97-102.

13. Maixner, M., Ahrens, U., and Seemüller, E. 1995. Detection of the German grapevine yellows (Vergilbungskrankheit) MLO in grapevine, alternative hosts and a vector by a specific PCR procedure. Eur. J. Plant Pathol. 101:241-250.

14. Maixner, M., Langer, M., and Gerhard, Y., 2006. Epidemiological characteristics of Bois noir type I. In: Extended Abstr. 15th Meet. ICVG, Stellenbosch, South Africa.

15. Marcone, C., Neimark, H., Ragozzino, A., Lauer, U., and Seemüller, E. 1999. Chromosome sizes of phytoplasmas composing major phylogenetic groups and subgroups. Phytopathology 89:805-810.

16. Marzachì, C. 2006. Stolbur phytoplasma. Pages 365-386 in: Characterization and Identification of Phytoplasmas. N. A. Harrison, G. P. Rao, and C. Marcone, eds. Studium Press, Texas.

17. Marzachì, C., Alma, A., D'aquilio, M., Minuto, G., and Boccardo, G. 1999. Detection and identification of phytoplasmas infecting cultivated and wild plants in Liguria (Italian Riviera). J. Plant Pathol. 81:127-136.

18. Marzachì, C., Veratti, F., and Bosco, D. 1998. Direct PCR detection of phytoplasmas in experimentally infected insects. Ann. Appl. Biol. 133:4554.

19. Minucci, C., and Boccardo, G. 1997. Genetic diversity in the Stolbur phytoplasma group. Phytopathol. Mediterr. 36:45-49.

20. Pacifico, D., Cimerman, A., Marzachì, C., and Foissac, X. 2006. Genetic diversity of Stolbur phytoplasmas assessed by PCR-RFLP and sequencing of a non-ribosomal gene encoding a putative membrane protein. Page 122 in: Proc. 16th IOM Congress, Cambridge, UK.

21. Palermo, S., Elekes, M., Botti, S., Ember, I., Alma, A., Orosz, A., Bertaccini, A., and Kölber, M. 2004. Presence of stolbur phytoplasma in Cixiidae in Hungarian vineyards. Vitis 43:201-204.

22. Pasquini, G., Ferretti, L., and Barba, M. 2007. Diffusione del Legno nero della vite nel Lazio e caratterizzazione molecolare dell'agente eziologico. Inf. Fitopatol. 4:42-47.

23. Romanazzi, G., Murolo, S., Terlizzi, F., Talevi, S., Stimilli, G., and Savino, V. 2007. Fitoplasmi associati ai giallumi della vite nelle Marche. Inf. Fitopatol. 57:48-50.

24. Schneider, B., Gibb, K. S, and Seemüller, E. 1997. Sequence and RFLP analysis of the elongation factor $T u$ gene used in differentiation and classification of phytoplasmas. Microbiology 143:3381-3389.

25. Schneider, B., Seemüller, E., Smart, C. D., and Kirkpatrick, B. C. 1995. Pages 369-380 in: Phylogenetic Classification of Plant Pathogenic Mycoplasmalike Organisms or Phytoplasmas. S. Razin and J. G. Tully, eds. Academic Press, New York.

26. Sforza, R., Clair, D., Daire, X., Larrue, J., and Boudon-Padieu, E. 1998. The role of Hyalesthes obsoletus (Hemiptera: Cixiidae) in the occurrence of Bois noir of grapevine in France. J. Phytopathol. 146:549-556.

27. Trivellone, V., Pinzauti, F., and Bagnoli B. 2005. Reptalus quinquecostatus (Dufour) (Auchenorrhyncha Cixiidae) as a possible vector of stolbur-phytoplasma in a vineyard in Tuscany. Redia 88:103-108.

28. Weber, A., and Maixner, M. 1998. Survey of populations of the planthopper Hyalesthes obsoletus Sign. (Auchenorrhyncha: Cixiidae) for infection with the phytoplasma causing grapevine yellows in Germany. J. Appl. Entomol. 122:375-381.

29. Weintraub, P. G, and Beanland, L. 2006. Insect vectors of phytoplasmas. Annu. Rev. Entomol. 51:91-111. 